\title{
Electrochemical and photoelectrochemical studies of C. I. Acid Orange 52 oxidation
}

\author{
Rafat Sałata ${ }^{1}$ Ewa Chrześcijańska², Jolanta Sokołowska ${ }^{1, *}$ \\ ${ }^{1}$ Institute of Polymer and Dye Technology, Lodz University of Technology, Stefanowskiego 12/16, \\ 90-924 Lodz, Poland \\ ${ }^{2}$ Institute of General and Ecological Chemistry, Lodz University of Technology, Żeromskiego 116, \\ 90-924 Lodz, Poland \\ *E-mail: jsokolow@p.lodz.pl
}

doi: $10.20964 / 2019.05 .56$

Received: 2 January 2019 / Accepted: 1 March 2019 / Published: 10 April 2019

\begin{abstract}
Basic electrochemistry (oxidation) of C. I. Acid Orange 52 at a platinum electrode was investigated. The electrochemical and photoelectrochemical oxidation of C. I. Acid Orange 52 were also conducted using a titanium electrode coated with a mixture of $\mathrm{TiO}_{2} / \mathrm{RuO}_{2}$. The conversion of the dye was observed as a change in absorbance $\left(\eta_{\text {Abs }}\right)$ at $\lambda_{\max }$, total organic carbon $\left(\eta_{\text {TOC }}\right)$ and chemical oxygen demand ( $\left.\eta_{C O D}\right)$. Quantum chemical calculations were conducted using the B3LYP/6-31G+ density functional theory (DFT) and AM1 method with HyperChem software to predict the primary oxidation products.
\end{abstract}

Keywords: electrochemical oxidation, photoelectrochemical oxidation, quantum chemical calculation, DFT.

\section{$\underline{\text { FULL TEXT }}$}

(C) 2019 The Authors. Published by ESG (www.electrochemsci.org). This article is an open access article distributed under the terms and conditions of the Creative Commons Attribution license (http://creativecommons.org/licenses/by/4.0/). 